\title{
Peningkatan Kreativitas Masyarakat melalui Usaha Produk Olahan Tanaman Palawija di Nagari Sungai Durian, Solok, Sumatera Barat
}

\section{(Community Creativity Improvement through Secondary Crop Processing Product in Nagari Sungai Durian, Solok, West Sumatera)}

\author{
Yulmira Yanti ${ }^{*}$, Munzir Busniah ${ }^{1}$, Zulfadly Syarif ${ }^{2}$, Intan Sari Pasaribu ${ }^{3}$ \\ ${ }^{1}$ Program Studi Proteksi Tanaman, Fakultas Pertanian, Universitas Andalas, Kampus Unand Limau Manis, \\ Pauh, Kota Padang, Sumatera Barat 25163. \\ 2Jurusan Budidaya Pertanian, Fakultas Pertanian Universitas Andalas, Kampus Unand Limau Manis, \\ Pauh, Kota Padang, Sumatera Barat 25163. \\ 3 Program Studi Agroekoteknologi, Fakultas Pertanian Universitas Andalas, Kampus Unand Limau Manis, \\ Pauh, Kota Padang, Sumatera Barat 25163. \\ *Penulis Korespondensi: yy.anthie79@gmail.com \\ Diterima November 2017/Disetujui Desember 2018
}

\begin{abstract}
ABSTRAK
Program pengabdian masyarakat ini dilatarbelakangi melimpahnya hasil tanaman palawija yang ada di Nagari Sungai Durian. Hal ini dikarenakan tanah dan kondisi iklim di Nagari Sungai Durian tidak cocok untuk budi daya tanaman padi, sehingga masyarakat setempat memilih untuk melakukan budi daya tanaman palawija. Tanaman palawija yang banyak dibudidayakan ialah tanaman jagung dan ubi kayu. Jagung dan ubi kayu merupakan tanaman yang mengandung karbohidrat yang tinggi, namun nilai jual dari hasil panen jagung dan ubi kayu terbilang rendah. Selain itu, olahan jagung dan ubi kayu yang tidak bervariasi mengurangi daya beli dari konsumen, sehingga perlu diciptakan berbagai olahan jagung dan ubi kayu yang kreatif dan inovatif. Tujuan dari kegiatan pengabdian masyarakat ini ialah meningkatkan kreativitas masyarakat Nagari Sungai Durian dalam menghasilkan berbagai olahan tanaman palawija khususnya jagung dan ubi kayu menjadi produk makanan yang memiliki nilai ekonomis. Pengabdian dilakukan dengan cara sosialisasi dan demo langsung pengolahan hasil palawija seperti jagung dan ubi kayu serta pemasaran produk dengan target sasaran, yaitu kelompok wanita Nagari Sungai Durian. Kegiatan ini menunjukkan respons positif dari masyarakat yang ditunjukkan dari antusias peserta dalam mengikuti kegiatan serta terbentuknya usaha olahan produk tersebut di Nagari Sungai Durian. Selain itu, kegiatan ini juga menambah peluang usaha bagi masyarakat Nagari Sungai Durian sehingga dapat meningkatkan pendapatan masyarakat. Luaran yang diperoleh dari kegiatan ini ialah: a) Terciptanya pemahaman masyarakat akan pentingnya berwirausaha; b) Keterampilan masyarakat dalam mengolah berbagai produk makanan; c) Menciptakan peluang usaha bagi masyarakat; d) Produk makanan yang siap dipasarkan; dan e) Peningkatan pendapatan masyarakat.
\end{abstract}

Kata kunci: jagung, peluang usaha, tanaman palawija, ubi kayu, wirausaha

\begin{abstract}
This community service program were based on the abundance of secondary crops in the Nagari Sungai Durian. This is because the soil and climate conditions in Nagari Sungai Durian are not suitable for cultivation of rice, so that local people choose to do cultivation of secondary crops. The most widely cultivated secondary crops are corn and cassava. Corn and cassava are crops that contain high carbohydrates. However, the selling value of corn and cassava yields were low. In addition, the processing product of corn and cassava do not vary, reduce the purchasing power of consumers. Then it is necessary to create a variety of processing product of corn and casava that are creative and innovative. The purpose of this community service activity is to increase the creativity of Nagari sungai durian community in producing various processed crop products especially corn and cassava into processing products that have economic value. This community service was done by socialization and secondary crops (cassava and maize) processing demo and the marketing of the products. This service was got positive response from the target community which shown by the participants enthusiasm and the new business formed after the service in Nagari Sungai Durian. This activity also increase business opportunities for Nagari Sungai Durian community so that it can increase the income of the community. Outcomes obtained from this activity are: a) The creation of public understanding in the importance of entrepreneurship; b) Community skills in processing various food products; c) Creating business opportunities for the community; d) Food products; e) Increase in communities incomes.
\end{abstract}

Keywords: business opportunity, cassava, corn, crops, entrepreneurship 


\section{PENDAHULUAN}

Nagari Sungai Durian merupakan salah satu nagari yang berada di Kecamatan IX Koto Sungai Lasi. Nagari ini berjarak $30 \mathrm{~km}$ dari Pusat Kota Solok. Selain jarak yang cukup jauh, akses yang dilalui untuk dapat ke nagari ini juga cukup sulit karena letak Nagari Sungai Durian yang berada pada daerah perbukitan. Nagari ini juga mengalami kesulitan akses air karena letak geografis nagari (PU 2014), sehingga lahan-lahan potensial di nagari ini tidak cocok dikembangkan sebagai sentra produksi hortikultura dan padi sawah. Oleh karena itu, masyarakat Sungai Durian memilih aternatif untuk menanam tanaman palawija.

Palawija merupakan kelompok komoditas tanaman pangan kedua terpenting setelah padi. Jagung, kedelai, dan kacang tanah merupakan komoditas palawija utama yang diusahakan petani pada musim kemarau pada berbagai jenis pengairan di lahan sawah (Rusastra et al. 2004). Tanaman palawija mampu menghemat air di musim kering sehingga cocok ditanam pada saat musim kemarau ataupun pada daerah yang memiliki kesulitan air. Pengembangan tanaman palawija di nagari ini juga akan turut mendukung program pemerintah dalam menggalakkan diversifikasi pangan di Indonesia demi mempertahankan ketahanan pangan sesuai dengan Peraturan Pemerintah No. 68 tahun 2002 tentang Ketahanan Pangan dan Peraturan Presiden No. 22 tahun 2009 tentang Percepatan Penganekaragaman Konsumsi Pangan.

Tanaman palawija yang dihasilkan oleh masyarakat Nagari Sungai Durian ialah jagung dan ubi kayu. Jagung dan ubi kayu merupakan tanaman yang memiliki karbohidrat dan kandungan pati yang tinggi. Kedua tanaman ini dapat dijadikan makanan pokok pengganti nasi. Kandungan gizi yang tinggi inilah yang menyebabkan keduanya sangat diminati masyarakat. Jagung memiliki komposisi protein sebesar 8-12\%, serat kasar 0,8-2,5\%, dan karbohidrat 68-73\% (Ullah et al. 2010). Jagung mempunyai banyak manfaat salah satunya untuk mencegah kanker (Jayaram et al. 2015). Menurut Bourdoux et al. (1982), ketela sebagai sumber tanaman pangan mempunyai komposisi gizi karbohidrat 34,7-37,9\%, protein 0,8-1,2\%, lemak 0,3\%, kalsium $33 \mathrm{mg}$, pospor 40 $\mathrm{mg}$, zat besi 0,7-0,8 mg, dan karoten (vitamin A) 365-380 SI serta kalori sebesar 142-146 kalori.

Jagung dan ubi kayu yang dihasilkan belum dimanfaatkan dengan baik oleh masyarakat Nagari Sungai Durian. Hasil tanaman ubi kayu dan jagung terkadang tidak mampu memenuhi kebutuhan hidup dari masyarakat. Hal ini dikarenakan minat masyarakat terhadap jagung dan ubi kayu masih rendah, nilai jual dari hasil tanaman palawija ini juga menurun. Selain itu, olahan jagung dan ubi kayu yang biasa dihasilkan sangat sederhana dan tidak menarik. Alternatif yang harus dilakukan ialah membuat berbagai olahan hasil tanaman palawija menjadi produk makanan yang kreatif dan inovatif, sehingga dapat meningkatkan nilai ekonomis dari hasil tanaman palawija tersebut.

Potensi pengusahaan jagung dan ubi kayu sangat menjanjikan sebagai makanan ringan/ cemilan (Winarno 2000; Suprapti 2002; Yogha \& Nurani 2010), karena bahan baku jagung dan ubi kayu di Nagari Sungai Durian yang melimpah, bahan pembantu mudah didapat dan teknologi pengolahannya relatif mudah dan ekonomis. Berkembangnya teknologi pengolahan jagung dan ubi kayu memberikan nilai tambah dan dapat menyerap tenaga kerja di sekitar lokasi usaha, sehingga meningkatkan pendapatan dan kesejahteraan masyarakat (Damardjati et al. 2000; Kuswanto 2001).

Tujuan dari kegiatan pengabdian masyarakat ini ialah meningkatkan kreativitas masyarakat Nagari Sungai Durian dalam menghasilkan berbagai olahan tanaman palawija khususnya jagung dan ubi kayu menjadi produk makanan yang memiliki nilai ekonomis. Selain itu, kegiatan ini juga menambah peluang usaha bagi masyarakat Nagari Sungai Durian sehingga dapat meningkatkan pendapatan.

\section{METODE PELAKSANAAN KEGIATAN}

Program pengabdian masyarakat ini dilaksanakan pada bulan Juli-Agustus 2017 dengan lokasi kegiatan di Nagari Sungai Durian, Kecamatan Sungai Lasi, Kabupaten Solok, Sumatera Barat (Gambar 1). Peserta kegiatan ini ialah mahasiswa KKN 2017 dan masyarakat Nagari Sungai Durian.

Bahan yang digunakan untuk olahan ubi kayu dan jagung meliputi: ubi kayu, mocav, jagung, tepung jagung, maizena, terigu, telur, metega, susu bubuk, bumbu aneka rasa, vanili, baking powder, gula halus, gula pasir, keju, masako, minyak goreng, tepung panir, dan bahan pendukung lainnya. Sedangkan alat yang digunakan untuk olahan produk ubi kayu dan jagung meliputi: kompor gas, oven, blender, mikser, loyang aluminium, parutan, cetakan rengginang, nampan, baskom, pisau, dandang, kuali, sendok 
penggoreng dan pengiris, ayakan, cetakan kue, dan lain-lain.

Program pengabdian masyarakat ini dilakukan dengan tiga tahap, yaitu persiapan, pelaksanaan, dan evaluasi

- Tahap persiapan, menyediakan bahan baku serta peralatan yang dibutuhkan dan melakukan uji coba pembuatan olahan hasil tanaman palawija.

- Tahap pelaksanaan, target utama program ini adalah masyarakat Nagari Sungai Durian, terutama dari kelompok wanita. Pemberian materi mengenai cara pengolahan berbagai macam produk yang berbahan dasar jagung dan ubi kayu. Adapun produk yang disosialisasikan cara pengolahannya adalah dendeng pucuk ubi, getuk lindri, nugget ubi kayu, kripik jagung, puding jagung, dan jagung susu keju (jasuke). Setelah pemberian materi, dilanjutkan dengan pelaksanaan demo masak untuk melihat secara langsung proses pembuatan produk tersebut. Pemberian selebaran cara pengolahan tiap-tiap produk yang diolah agar masyarakat dapat mencoba dan menerapkannya (Gambar 2).

- Tahap evaluasi, tolak ukur keberhasilan dari sosialisasi dan pelatihan pengolahan hasil tanaman palawija adalah masyarakat Nagari Sungai Durian mampu mengolah dan memproduksi sendiri produk dari hasil tanaman palawija yang dibudidayakan. Kegiatan tersebut juga dapat dikembangkan lebih lanjut sehingga menjadi peluang untuk berwirausaha.

\section{HASIL DAN PEMBAHASAN}

\section{Penyuluhan dan Diskusi}

Penyuluhan dilakukan di gedung balai serba guna Nagari Sungai Durian dengan melibatkan aparat pemerintahan nagari dan masyarakat setempat. Adapun materi yang diberikan ialah cara pengolahan hasil tanaman palawija dan

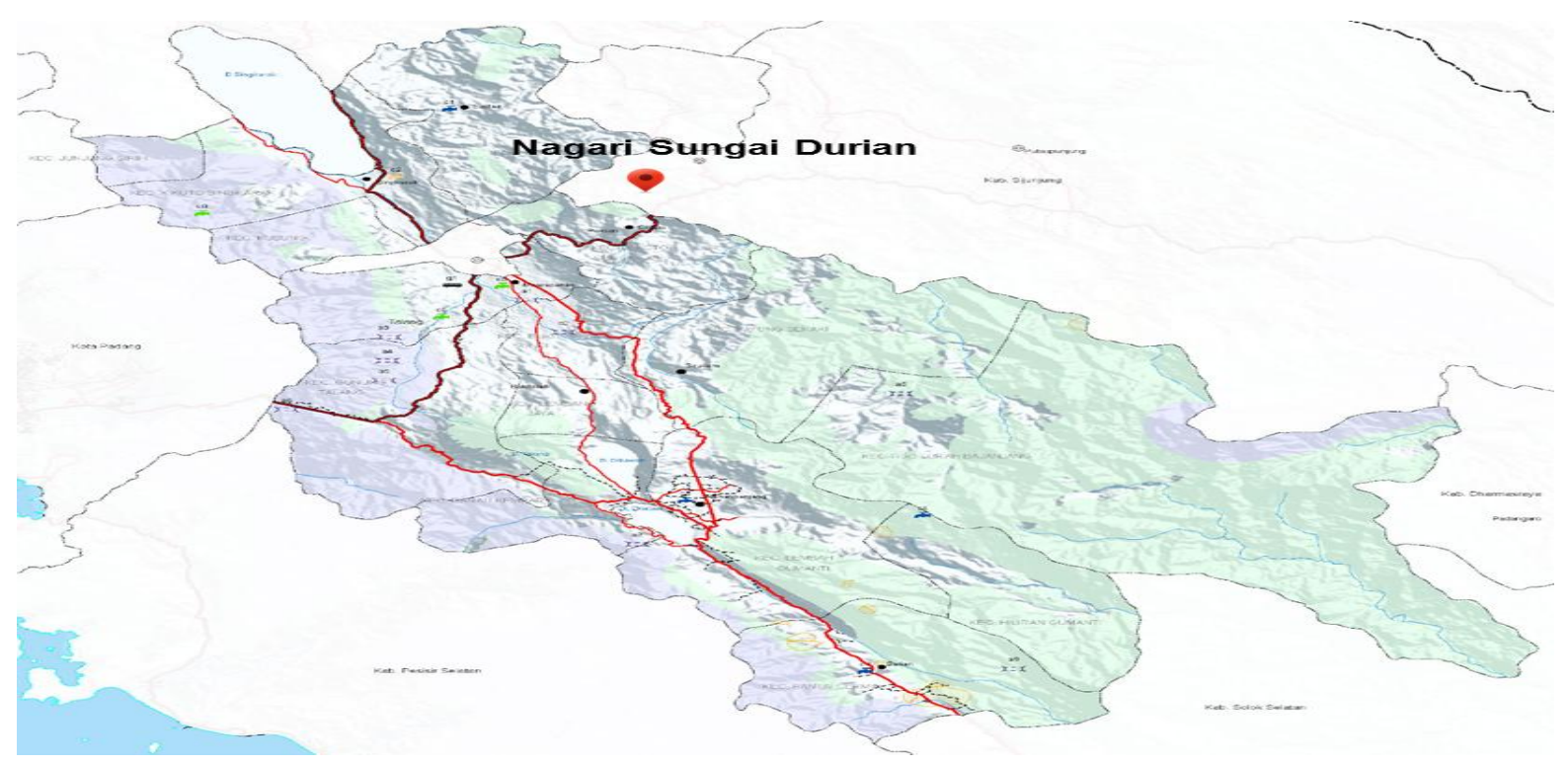

Gambar 1 Peta Kabupaten Solok.



Gambar 2 Skema kegiatan. 
analisis usaha produk olahan tanaman palawija. Masyarakat diberikan pemahaman terhadap pentingnya dilakukan pengolahan hasil tanaman palawija dibandingkan menjual hasil produksi secara langsung ke pasar. Hal tersebut tentu berpengaruh terhadap nilai jual yang akan semakin tinggi jika diolah menjadi produk lain yang lebih bervariasi. Hasil yang diperoleh dari kegiatan penyuluhan ini ialah bertambahnya pemahaman dan keterampilan masyarakat dalam mengolah hasil tanaman palawija.

Tantangan pokok yang dihadapi dalam pengembangan pengolahan dan pemasaran produk palawija adalah perubahan lingkungan ekonomi regional dan internasional, tuntutan pasar atas peningkatan efisiensi usaha, dinamika permintaan, dan perubahan preferensi pasar terkait dengan informasi nutrisi dan jaminan kesehatan dan keamanan produk pertanian. Permasalahan pengembangan usaha pengolahan terkait dengan skala usaha, standar penanganan produk, kinerja tekonologi, dan mutu produk yang dinilai masih rendah. Kelemahan mendasar dalam programprogram pengembangan kreativitas masyarakat berbasis usaha produk olahan terletak pada pemahaman bahwa usaha tersebut diartikan dalam aspek ketersediaan semata, sementara aspek distribusi dan konsumsi belum banyak mendapatkan perhatian. Ketersediaan pangan per kapita tercukupi secara statistik, tidak menjamin seluruh rumah tangga tercukupi kebutuhan gizinya, karena belum tentu produk terdistribusi merata keseluruh rumah tangga, sehingga tidak menjamin seluruh rumah tangga terpenuhi secara cukup, baik jumlah dan mutunya, aman, merata, terjangkau, serta sesuai dengan selera (preferensi) individu-individu dalam rumah tangga. Oleh sebab itu, pengolahan hasil palawija menjadi produk olahan yang baru, memiliki rasa yang sesuai dengan preferensi masyarakat serta terjangkau berpotensi untuk dikembangkan bagi masyarakat pedesaan seperti Nagari Sungai Durian.

\section{Demonstrasi dan Pelatihan}

Pada pelatihan pembuatan produk dihasilkan produk olahan jagung dan ubi kayu sebanyak 6 produk, yaitu dendeng pucuk ubi, nugget singkong, getuk lindri isi cokelat, jagung susu keju, keripik jagung, dan puding jagung (Gambar 3). Demonstrasi dan pelatihan berjalan dengan baik dan sukses, hal ini terlihat dari antusias masyarakat yang begitu tinggi. Selain melakukan demonstrasi dan pelatihan, dalam kegiatan ini juga dilakukan analisis usaha yang meliputi keuntungan yang didapatkan dari berbagai produk tersebut. Dari seluruh produk, jika diperkirakan seluruhnya memberikan keuntungan yang cukup tinggi, hal ini dapat dilihat dari Tabel 1.

Dari hasil kegiatan ini juga diperoleh produk yang telah siap dipasarkan dengan memakai label (Gambar 4). Produk makanan yang akan dipasarkan secara global atau keluar daerah harus memiliki izin dari BPOM dan label halal dari MUI.

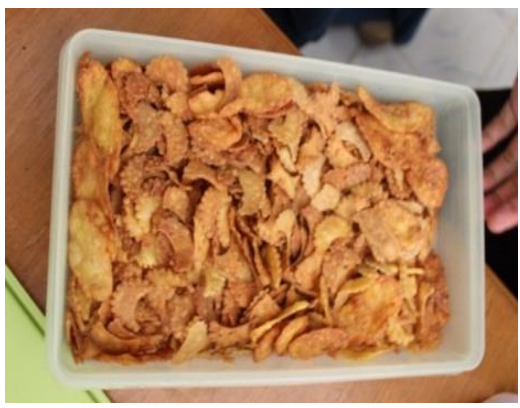

a. Keripik jagung

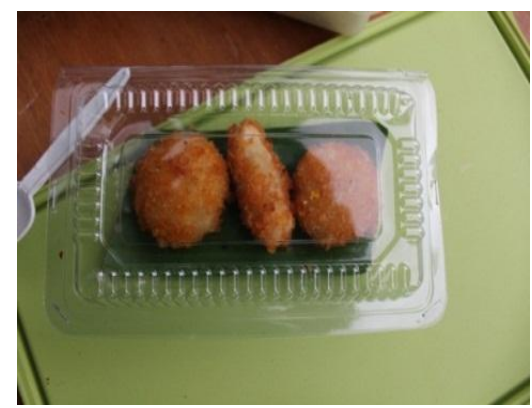

d. Nugget ubi kayu

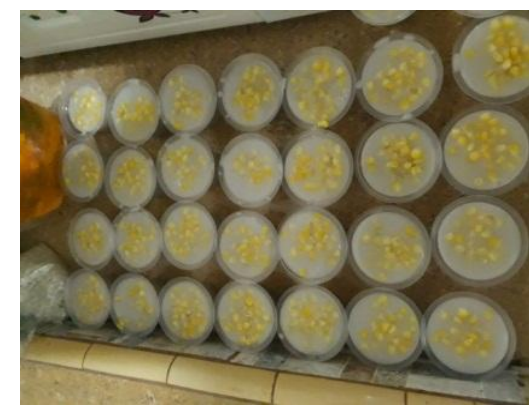

b. Puding jagung

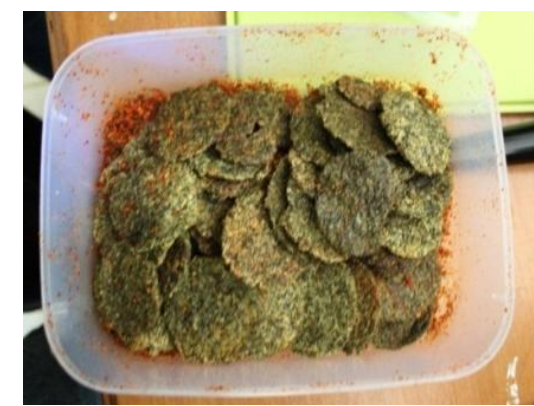

e. Dendeng pucuk ubi

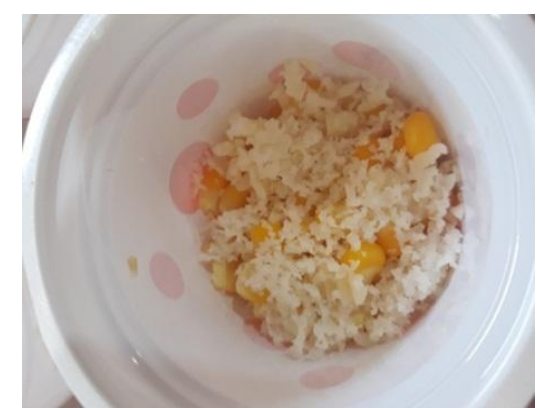

c. Jagung susu keju

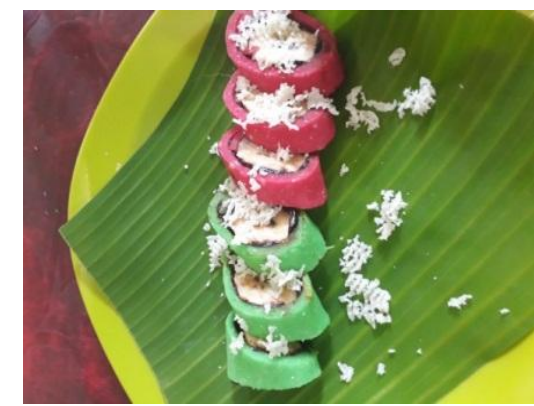

f. Getuk lindri

Gambar 3 Produk olahan jagung dan ubi kayu. 
Tabel 1 Analisis keuntungan setiap produk

\begin{tabular}{lccccc}
\hline \multicolumn{1}{c}{ Nama produk } & Modal (Rp) & Hasil (bungkus) & Harga jual (Rp) & Penjualan (Rp) & Keuntungan (Rp) \\
\hline Dendeng pucuk ubi & 56.000 & 50 & 2.000 & 100.000 & 44.000 \\
Getuk lindri & 56.000 & 50 & 2.000 & 100.000 & 44.000 \\
Nugget singkong & 47.000 & 75 & 1.000 & 75.000 & 28.000 \\
Keripik jagung & 35.000 & 60 & 1.000 & 60.000 & 25.000 \\
Jasuke & 39.000 & 30 & 2.000 & 60.000 & 21.000 \\
Pudding jagung & 33.000 & 40 & 1.500 & 60.000 & 27.000 \\
\hline
\end{tabular}

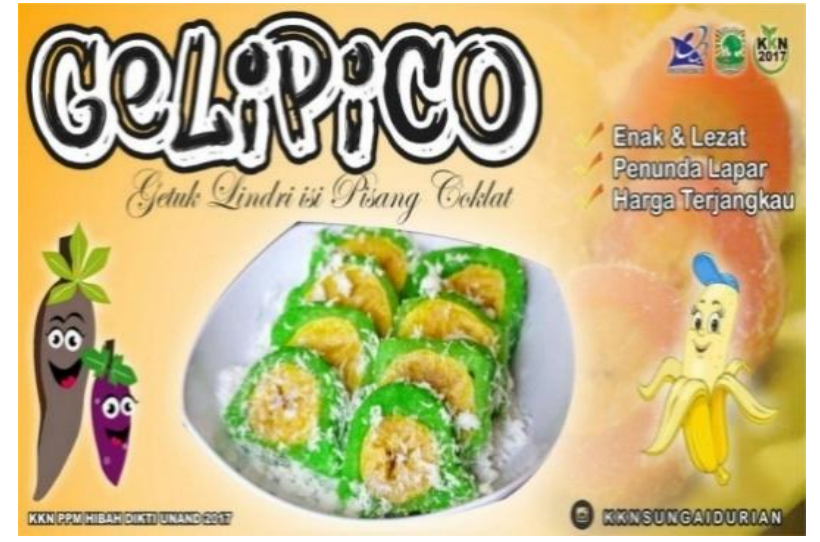

Gambar 4 Produk hasil olahan ubi kayu siap dipasarkan yang memakai label.

Hal inilah yang menjadi kendala dalam pemasaran produk olahan jagung dan ubi kayu yang telah dihasilkan masyarakat Nagari Sungai Durian. Diperlukan kegiatan berkelanjutan dalam menjadikan produk ini sebagai peluang bisnis yang menjanjikan bagi masyarakat, sehingga perlu dilakukan pendampingan yang berkelanjutan baik dari pihak Universitas Andalas dan pemerintah terkait.

\section{SIMPULAN}

Kegiatan ini sangat bermanfaat bagi masyarakat khususnya masyarakat Nagari Sungai Durian. Antusias dan partipasi aktif dari masyarakat sangat menunjang keberhasilan dari kegiatan ini. Kegiatan ini telah mampu memberikan keterampilan kepada masyarakat tentang membuat berbagai olahan jagung dan ubi kayu yang kreatif dan inovatif. Kegiatan ini juga membangun jiwa wirausaha pada masyarakat Nagari Sungai Durian. Luaran yang didapat adalah terciptanya pemahaman masyarakat akan pentingnya berwirausaha, keterampilan masyarakat dalam mengolah berbagai produk makanan, menciptakan peluang usaha bagi masyarakat, produk makanan yang siap dipasarkan, dan peningkatan pendapatan masyarakat

Diharapkan agar kegiatan ini bersifat berkelanjutan agar menjadikan produk olahan jagung dan ubi kayu sebagai bisnis yang menjanjikan bagi masyarakat khususnya masyarakat Nagari Sungai Durian. Pendampingan secara terus menerus dari pihak Universitas Andalas dan pemerintah terkait perlu dilakukan untuk meningkatkan keberhasilan dan pengembangan usaha dalam jangka panjang. Perluasan pasar untuk distribusi produk juga dibutuhkan untuk pengembangan usaha ini.

\section{UCAPAN TERIMA KASIH}

Penulis mengucapkan terima kasih kepada Kementrian Ristek dan Dikti Republik Indonesia yang telah mendanai program pengabdian masyarakat ini dengan nomor kontrak 012/SP2H/PPM/DRPM/IV/2017 tanggal 30 Maret 2017. Penulis juga mengucapkan terima kasih kepada Universitas Andalas yang telah mendukung berjalannya program ini. Ucapan terima kasih juga penulis sampaikan kepada wali nagari, staf pemerintahan, dan seluruh masyarakat Nagari Sungai Durian serta Mahasiswa KKN 2017.

\section{DAFTAR PUSTAKA}

Bourdoux P, Seghers P, Mafuta M, Vanderpas J, Vanderpas-Rivera M, Delange F, Ermans AM. 1982. Cassava products: HCN content and detoxification processes. In: Delange, F.; Iteke, F.B.; Ermans, A.M. (eds.). Nutritional factors involved in the goitrogenic action of cassava. Ottawa (CA): International Development Research Centre, 5158.

Damardjati DS, Widowati S, Wargiono J, Purba S. 2000. Potensi dan Pendayagunaan Sumber Daya Bahan Pangan Lokal Serealia, UmbiUmbian, Dan Kacang-Kacangan Untuk Penganekaragaman Pangan. Makalah Pada Lokakarya Pengembangan Pangan Alternatif. Jakarta (ID). 
Jayaram S, Kapoor S, Dharmesh SM. 2015. Pectic polysaccharide from corn (Zea mays L.) effectively inhibited multi-step mediated cancer cell growth and metastasis. Chemicobiological Interactions. 235: 63-75. https:// doi.org/10.1016/j.cbi.2015.04.008

Kuswanto KR. 2001. Pengendalian Mutu Dan Keamanan Pangan Lokal Dalam Mengantisipasi Pasar Global. Makalah Dalam Lokakarya Nasional Pengembangan Pangan Lokal. Badan Ketahanan Pangan Provinsi Jawa Timur, Surabaya (ID), 13-14 November 2001.

[PU] Kementerian Pekerjaan Umum dan Perumahan Rakyat Republik Indonesia. 2014. Peta Infrastruktur Kabupaten Solok (2014). [Internet]. [Diakses pada: 10 Mei 2016]. Tersedia pada: http://loketpeta. pu.go.id/peta-infrastruktur-kabupaten-solok2014.

Rusastra IW, Rachman B, Friyatno S. 2004. Analisis daya saing dan struktur proteksi komoditas palawija. Dalam Prosiding Efisiensi dan Daya Saing Sistem Usaha tani Beberapa
Komoditas Pertanian di Lahan Sawah. Badan Litbang Pertanian.

Suprapti LM. 2002. Tepung Kasava Pembuatan Dan Pemanfaatannya. Yogyakarta (ID): Kanisius.

Ullah I, Ali M. Farooqi A. 2010. Chemical and nutritional properties of some maize (Zea mays L.) varieties grown in NWFP, Pakistan. Pakistan journal of Nutrition. 9(11): 11131117. https://doi.org/10.3923/pjn.2010. 1113.1117

Winarno FG. 2000. Potensi Dan Peran TepungTepungan Bagi Industri Pangan Dan Program Perbaikan Gizi. Makalah Pada Semnas Interaktif: Penganeka-Ragaman Makanan Untuk Memantapkan Ketersediaan Pangan. Jakarta (ID), Oktober 2000.

Yogha S, Nurani AS. 2010. Potensi tepung singkong sebagai bahan industri kreatif kuliner boga. Makalah Prosiding ISBN 978602- 96174-0-5. Universitas Negeri Malang (ID). 